INTERNATIONAL JOURN AL OF RESEARCHES IN BIOSCIENCES, AGRICULTURE AND TECHNOLOGY (c) VISHWASHANTI MULTIPURPOSE SOCIETY (Global Peace Multipurpose Socie ty) R. No. MH-659/13 (N) www.vmsindia.org

\title{
INFLUENCE OF ARBUSCULAR MYCORRHIZAE ON GROWTH OF TEPHROSIA PURPUREA (L.) PERS.
}

\author{
N. B. Mane, C. J. Khilare and Y. T. Shinde ${ }^{3}$ \\ Yashvantrao Chavan Institute of Science, Satara ${ }^{1}$. \\ Botany Research laboratory, Dahiwadi College Dahiwadi ${ }^{2,3}$ \\ nbmane123@gmail.com
}

\begin{abstract}
:
The potential for arbuscular mycorrhizal fungi (AMF) to influence the host species depends on their affinities and effect. In the present investigation Acaulospora delicata, Glomus dimorphicum, Glomus fasciculatum, Glomus geosporum we re evaluated for their influence in improving the growth performance of Tephrosia purpurea Pers. After 45 and 90 days of inoculated plants showed better growth responses over control plants. The maximum mycorrhizal effect on experimental plants was obse rved by the Acaulospora delicata and Glomus dimorphicum in increasing height, biomass, AM spore number and percent root colonization.
\end{abstract}

Key Words: Arbuscular Mycorrhizal fungi, Tephrosia purpurea, Acaulosporadelicata, Inoculum .

\section{Introduction}

The genus Tephrosia purpurea (L.) or Sarpunkha is a wild legume, grows throughout India belonging to family Leguminosae (Sub family- Papilio naceae).

Microorganisms are present in great number near the fine feeder roots of most of the plant species and they play vital role in numerous physiological processes. These microbial processes are symbiosis. The most widespread symbiosis of plants is the mycorhizal association between root-inhabiting fungi and the feeder roots (Marx, 1997), K. Sambandan, 2014).

Mycorrhiza referes to an association or symbiosis between plants and fungi colonize the cortical tissue of roots during periods of active plant growth. AM fungi belonging to the phylum Glomeromycota are vital components of almost all land ecosystems. Frank (1885) coined the term "Mycorhiza", VAM which is an obligatory parasite belonging to the drder Glomales ( Morton and Benny, 1990). It enhances productivity of cereals, pulses, oil seed, vegetables and ornamental plants (Boddington and Dodd, 2000). AM fungal inoculation showed better performance in total seedling biomass and $\mathrm{P}$ up take in plant species ( Bukhari and Rodrigues, 2008), (Kumar and Aggarwal, 2009).

In the present study analysis has been made to see the effect of AM fungi Acaulospora delicata Glomus dimorphicum, Glomus fasciculatum and Glomus geosporum on different growth parameters of Tephrosia purpurea after 45 and 90 days of inoculation.

\section{Materials and Methods}

\section{Study site:}

The study was undertaken in polyhouse of Department of Botany and Recognised Research Lab. Dahiwadi College Dahiwadi affiliated to Shivaji University, Kolhapur (M.S.) India. Located at $17040^{\prime} \mathrm{N} 740$ 30' $\mathrm{E}$. The climate is an inland of Maharashtra. The temperature has a relatively high range between $15^{\circ} \mathrm{C}$ to $45^{\circ} \mathrm{C}$. Maximum temperature exceeds $40^{\circ}$. Every summer and typically ranges between 38 to 450 C. It receives very little rainfall from June to Septe mber and is conside red as a drought prone place by the government. Sometimes there is no rainfall during rainy season. The winter temperatures are significantly higher and humidity is low in this season.

\section{Sample Collection and Processing:}

Soil samples from the root zone of Tephrosia purpurea were collected to a depth of $5.30 \mathrm{~cm}$. The soil samples were wet-sieved for spores using the technique of Gerdemann and Nicolson (1963) and quantification of AM spores was done by grid line intersect method (Adholeya and Gaur, 1994). Root samples we re rinsed with tap water and cut into $1 \mathrm{~cm}$ pieces and performed with trypan blue according to rapid clearing and staining method of Philips and Haymann (1970). The percent AM root colonization was calculated by using the following formula.

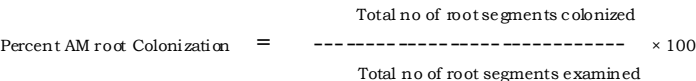


Mass Multiplication and inoculation of AM spores:

Dominant AM spores are Acaulospora delicata Glomus dimorphicum, Glomus fasciculatum and Glomus geosporum isolated from rhizosphere of T. purpurea, were mass produced by funnel technique ( Menge and Timmer, 1982) using maize as host. Seedlings of T. purpurea were grown in earthen pots (size $25 \times 25$ ) under polyhouse conditions in sterilized soil. To each pot $10 \%$ inoculums of AM fungi was added. The effect of diffe re nt treatements was recorded after 45 days and 90 days of inoculations on various growth parameter. Roots and shoots were harvested and weighted separately for their fresh weight and oven dried to $70^{\circ} \mathrm{C}$ for dry we ight.

\section{Results and Discussions:}

T. purpurea plant grown in the presence of AM fungi showed a general increase in plant height, shoot biomass (fresh and dry), root biomass (fre sh and dry), mycorrhizal parame te rs like percent colonization and spore number as those grown in soils withought AM fungus ( Table 1, 2). AM inoculation significantly increased the shoot length of $T$. purpurea after 45 days and 90 days increase shoot length was maximum in inoculation of AM fungi $G$. dimorphicum and A. delicata (Table1,2). This shows the efficacy of AM fungi on growth of $T$. purpurea. Vaingankar and Rodrigues highlighted shoot and root biomass (fresh and dry), plant height was greatly affected by $G$. intraradices during the initial stages of growth, such positive effects of mycorhizal inoculation on plant height were also observed by Long et al., (2010). Reena and Bagyaraj (1990) have reported that the present root colonization and AM spore count were increased by inoculation of $\mathrm{AM}$

Table -1. Influe nce of Arbuscular mycorrhizal fungi on plant growth performance of T. purpurea after 45 days.

\begin{tabular}{|c|c|c|c|c|c|c|c|}
\hline Treatments & $\begin{array}{c}\text { Change } \\
\text { in height } \\
\mathbf{c m}\end{array}$ & $\begin{array}{c}\text { Fresh } \\
\text { shoot } \\
\text { weight } \\
\mathbf{g m}\end{array}$ & $\begin{array}{c}\text { Dry } \\
\text { shoot } \\
\text { weight } \\
\mathbf{g m}\end{array}$ & $\begin{array}{c}\text { Fresh } \\
\text { root } \\
\text { weight } \\
\mathbf{g m}\end{array}$ & $\begin{array}{c}\text { Dry root } \\
\text { weight } \\
\mathbf{g m}\end{array}$ & $\begin{array}{c}\text { AM spore } \\
\text { nu mber } \\
\text { /20 gm }\end{array}$ & $\begin{array}{c}\text { Colonization } \\
\text { \% }\end{array}$ \\
\hline C & 10.03 & 0.29 & 0.03 & 0.33 & 0.02 & 25 & 9.83 \\
\hline T1 & 18.60 & 0.65 & 0.06 & 0.53 & 0.04 & 54 & 92 \\
\hline T2 & 18.80 & 0.68 & 0.07 & 0.58 & 0.05 & 57 & 95 \\
\hline T3 & 15.60 & 0.60 & 0.05 & 0.41 & 0.05 & 51 & 82 \\
\hline T4 & 16.30 & 0.55 & 0.06 & 0.53 & 0.04 & 53 & 70 \\
\hline
\end{tabular}

${ }^{*} \mathrm{C}$ - control, T1-A. delicata, T2-G. dimorphicum, T3-G. fasciculatum and T4- G. geosporum. Fig1. Influence of Arbuscular mycorrhizal fungi on plant growth parameters - AM sore number/20gm and percent colonization of T. purpurea after 45 days

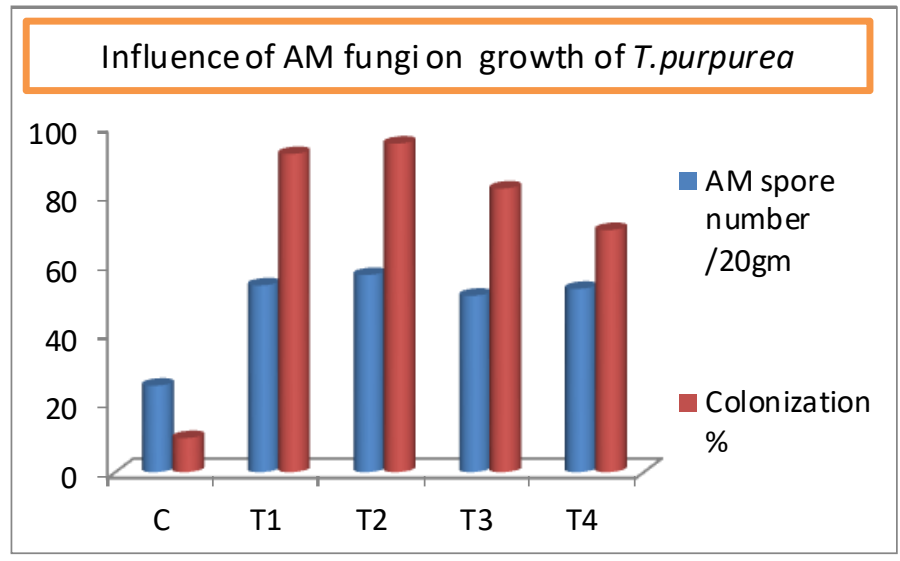


Table -2. Influence of Arbuscular mycorrhizal fungi on plant growth performance of T. purpurea after 90 days.

\begin{tabular}{|c|c|c|c|c|c|c|c|}
\hline $\begin{array}{c}\text { Treate } \\
\text { ments }\end{array}$ & $\begin{array}{c}\text { Change in } \\
\text { height } \\
\mathbf{c m}\end{array}$ & $\begin{array}{c}\text { Fresh } \\
\mathbf{s h o o t} \\
\text { weight } \\
\mathbf{g m}\end{array}$ & $\begin{array}{c}\text { Dry shoot } \\
\mathbf{w e i g h t} \\
\mathbf{g m}\end{array}$ & $\begin{array}{c}\text { Fresh root } \\
\mathbf{w e i g h t} \\
\mathbf{g m}\end{array}$ & $\begin{array}{c}\text { Dry root } \\
\mathbf{w e} \\
\mathbf{g m h}\end{array}$ & $\begin{array}{c}\text { AM spore } \\
\text { number/2 } \\
\mathbf{0} \mathbf{g m}\end{array}$ & $\begin{array}{c}\text { Colonizati } \\
\text { on } \\
\mathbf{\%}\end{array}$ \\
\hline $\mathrm{C}$ & 20.97 & 1.14 & 0.14 & 0.42 & 0.17 & 53 & 10 \\
\hline $\mathrm{T} 1$ & 54.97 & 1.52 & 0.38 & 0.83 & 0.22 & 88 & 90 \\
\hline $\mathrm{T} 2$ & 62.10 & 2.06 & 1.27 & 0.85 & 0.23 & 94 & 96 \\
\hline & 41.40 & 1.68 & 0.49 & 0.81 & 0.30 & 59 & 63 \\
\hline & 41.97 & 1.52 & 1.52 & 0.83 & 0.22 & 94 & 88 \\
\hline
\end{tabular}

\section{Acknowledgement:}

Author Mane N. B. thankful to University Grants Commission (WRO) Pune (M.S.) for awarding Teacher fellowship F. No. 36-16/12, 14 January 2013. Authors are greatly thankful to Principal, Yashvantrao Chavan Institute of Science, Satara (M.S.) and Principal, Dahiwadi College, Dahiwadi for their constant encouragement and providing necessary laboratory facilities.

\section{References:}

Adholeya, A. and Gaur, A. (1994). Estimation of VAM fungal spores in soil. Myco, News 6(1): 1011 .

Boddington, C.L., Dodd, J.C., 2000. The effect of agricultural practices on the development of indigenous arbuscular mycorrhizal fungi. I. Field studies in an Indonesian ultisol. Plant Soil 218, 137-144.

Gerdemann J .W., and Y. H. Nicolson, 1963. Spores of mycorrhizae Endogone species extracted from soil by wet sieving and decanting. Transaction of the British Mycol. Society, $46: 235-244$.

Long, L.K. , Huang, Y.H., Guo, J, Zhu, H.H.(2010). Effects of arbuscular mycorrhizal fungi on Zinnia and the different colonization between Gigaspora and Glomus. World j. Microbiol Bio te chnol. 26: 1527-153 1.

Mehtab j. Bukhari, and B.F. Rodrigues. (2008). Effect of Arbuscular Mycorhizal fungi on growth of Artocarpus heterophyllus and Syzygium cumini Seedlings in Iron ore Mine Rejects. J Mycol P1 Pathol, Vo1, 38 No 2. p.p.238-242.
Menge, J.a. and Timmer, L.M. (1982) Procedure for inoculation of plants with VAM in the laboratory, greenhouse and field, 59-68, In; shenck, N.C. (ed), Methods and principles of Mycorrhizal Research.. A.P.S. Pree, St. Paul, Minnesota.

Morton J.B. and Benny G.L. (1990). Revised classification of arbuscular mycorrhizal fungi, (Zygomycetes) : a new order Glomales, two suborders, Glomineae and Gigasporineae, and two new families, Acvaulosporaceae and Gigasporaceae, with an amendation of Glomaceae. Mycotaxon. 37:471-491.

Phillips J.M., AND D.S. Hayman, 1970.Improved procedure for clearing roots and staining parasitic and vesicular-arbuscular mycorrhizal fungi for rapid assessment of infection.Trans. Br. Mycol.So c. 5 5:158-161

Reena, J and Bagyaraj, D.J. (1990. Responces of Acacia nilotica and Calliandra calothyyrus to different VA mycorrhizal fungi. Arid soil Re search and Re habiliation. 4;261-268.

Sambadan, K. and Mark, D. H., (2014). Studies on Arbuscular Mycorrhizal (AM) profiles of coastal soils in Karaikal dis trict, International journal of multidisciplinary and current Re search.ISBN: 2321-3124.

Vaingankar J.D. and Rodrigues, B.F. (2012). Screening for efficient AM fungal bioinoculants for two commercially important ornamental flowering plant species of Asteraceae. Biological agriculture and horticulture Vol. 28. No.3, September 167-176. 